\title{
Height as an expression of life histories: A study of intergenerational variation and determinants among tribal men
}

\author{
Krishna Kumar Choudhary
}

Ph.D. scholar, Centre of Social Medicine and Community Health, Jawaharlal Nehru University, New Delhi, Delhi, India

Corresponding Author:

Email: krishnavagda@gmail.com

\begin{abstract}
Introduction: Despite the advertised impressive economic growth, stunting in children continues to be an important problem in India demanding further exploration of enigma of height. Role of socio-economic factors, environmental variables and genetic factors have been documented. Till recent past it was also argued that Indians are a different genetic pool and would need separate standards for measuring heights. It is important to understand phenomenon of height and its determinants.

Objective: The aim of the study is to identify the intergenerational variation in adult height among tribal men and its determinants; to understand the structural changes in the pattern of food composition and adequacy in the neoliberal era, and illness histories along with changes in the health care service accessibility for understanding determinants of the height.

Materials and Method: Two groups of villages were selected with different developmental levels as reflected in their backwardness, road connectivity, employment opportunities and poverty levels from Salumber Block in Rajasthan. The social history of these two groups of villages was collected through key person interviews and available records to understand the changes happening in living condition over a period of time. Average heights of adults and its patterns from the selected six villages were assessed through a sample of 573 adult men. The selection of 573 men was done through systematic sampling process household. Adult male (20-60 years) of every 3rd household were the part of study for analysis of the intergenerational variation. Childhood history of 120 adult males (10 from each stratum of 20-40 years and 40-60 years) was collected from every 5th household for detailed analysis of determinants of height. The childhood history was corroborated with the parents/guardian/caretaker or elder person of the family member who observed the growing periods of respondents. Women respondents were excluded from the study due to the corroboration issues. Because before and after 20 years women left their parental house due to marriage. So, in that case researcher was unable to track the person who observed the growing age periods of women. The selection of generations is based on the age group division. Age group 20-40 and 40-60 represent current generation and earlier generation, respectively.

Results: The average heights of tribal men from six villages are $162.19 \mathrm{~cm}$ (95\% CI (161.74-162.64, p-0.001). The Meena community from the group two villages showed significant improvement in current height about $2.17 \mathrm{~cm}$ (p-0.002) while group one villages showed decline in average height of current generation about $1.05 \mathrm{~cm}$. The days of food shortage and reported hunger in the growing age/years is inversely associated with average height gain (p-0.001). The frequency of pulses and dairy product consumption significantly associated with average height gain (p-0.03 and 0.001 , respectively). Occurrence of disease and recurrence of disease in the growing age is significantly and inversely associated with height gain (p-0.001). The episodes of diarrhoea in the growing age were observed to be a major impediment of the height growth (95\%CI, 21.48-24.40, p-0.001). The villages where the employment opportunities are frequently available round the year showed improvement in the average height of current generation.

Conclusion: The average height of the current generation is marginally improved. Changes in the pattern of food consumption and adequacy affected the average height of current generation in the new globalization era. Adequate nutrition intake, lower exposure to disease environment, and better access to health care services is positively and significantly correlated with height gain of the individual.
\end{abstract}

Keywords: Intergenerational, Height, Tribal, Nutrition, Hunger, Disease.

\section{Introduction}

The available literature of/about height gain pointed that height is a key measure of physical wellbeing and the biological standard of living. The height of a child or an adult is a crucial indicator that cannot be regained in a shorter period of the lifecycle(Bailey, Hatton, \& Inwood, 2016; Garcia \& Quintana-Domeque, 2007; Hatton \& Bray, 2010) Indeed, an ideal situation, from 0 to end of 2 years of age the maximum cumulative height gains by $80-90 \mathrm{~cm}$, from 3 to 7 years about $120 \mathrm{~cm}$, from 7 years to 14 years height gain up to $160 \mathrm{~cm}$, and later phase of adolescence period (14 to 18 years) about 170 to $180 \mathrm{~cm}$. In adolescent period, highest height gain process recorded about 40 to $50 \mathrm{~cm}$ (Bogin, 1999).

Human stature/height reflects or manifests an individual's nutritional needs. Nutritional security, living condition, access to health services play an important role or are determinants of height gain (Komlos \& Baur, 2004; Steckel, 1995; VOTH \& Leunig, 1996). Food availability and dietary intake influences the height gain process and additionally, the socio-economic status plays a very significant role in the spatial variation of height (Bailey et al., 2016). For example, height data of German civilians demonstrates that the World Wars made a substantial decline in the heights of children due to hunger. However, German 
population recovered their height after the war period. (Dougherty, 1998).

Despite the impressive economic growth of the Indian economy after the new globalization era(Chesters, 2016), the current generation of study showed mixed result about height gain. Meena community from the group one villages (Ghati, Panikotada, and Kalimagari showed declined in the average height of current generation while group two villages (Morila, Ven, and Sarwani) showed significant improvement in the average height of the current generation. The determinants of the height and changes in new globalization era clearly explained these variations. The National debate by the government of India's primer program implementation body indicate that India's nutritional problem is less as international growth reference showed. The dy. Chief argued that we need to reframe the indices of nutritional status (Panagariya \& Bhagwati, 2013). This paper includes first introduction, second methodology adopted, third result and discussion, and last is conclusion of the study.

\section{Materials and Method}

The study tried to identify the intergenerational variation in adult height and the social determinants of these variations. The design of this study would involve first assessment of the heights of adults to see if there is any change over time in average heights and then a retrospective enquiry of their life histories to understand effect of different determinants over their growing age on the height. The childhood histories of adults are collected in presence of and along with other elderly family members who were witness to or part of their growing age. Given the possibilities of inadequacies in the life histories reported because of difficulties in recollection and recall bias it was important for the study to get an idea about overall developmental history and the social history of the study area and put these life histories in the context. Social history of the village provides the context to understand the life histories and was also helpful in corroborating / triangulating the life histories reported.

A portable Stadiometer, with the sensitivity of $+/-1$ $\mathrm{mm}$ was used for measurement of height of adult males.

\section{Study Area}

This study included six villages from the two sets of the location of the Salumber block of Udaipur district in Rajasthan. Two sets of villages were selected for this study: one set of villages (Ghati, Panikotada, and Kalimgari) relatively backward area with poor connectivity and transportation. These villages are surrounded by the Jaisamand lake. It was assumed that presence of such huge water body would assure good crop yield. Since 1972, Government of Rajasthan permitted fishing in the lake for local population without any charges. It is assumed that this would facilitate inclusion of fish in local food basket and income generation by selling of fish. Another set of villages (Morila, Ven and Sarwani) chosen were also backward but were relatively better as compared to the first group. It was relatively closer to the block town of Salumber and had better road connectivity and transportation. These villages were located near mining area. The mining was started in Morila village in 1962. People from the nearby villages (Ven, Sarwani, Morila, Kevda, Samarjhap, Boraj, Bra, Rajpura) got daily wage work in the mines. It was assumed that this assured work and income reflected in their food consumption.

Exploration of the field was started in September 2016 with the process of recording social history of the villages. Two age groups were recruited for the study; one is 20-40 years and another is 40-60 years for the analysis. The reason behind the strata of two group was derived from the social history of the villages that provided evidences that how the changes in before 20 to 40 years ago (mainly changes in 1970s to 1990s) affects the height of individual. Researcher assumed that the birth year 1955 to 1975 and 1975 to 1995 for the age group of 40-60 year and 20-40 year, respectively. As per the birth year, the expected growing year of 20-40 years age group was 1975 to 2015, subsequently 1955 to 1995 for the age group of 40-60 years. However, the year 1975 to 1995 affects the both age groups. The age group of 20-40 represent the current generation and 40-60 years represent the previous generation

\section{Sampling}

To avoid the possible difficulties in interpretation due to population group belonging to different caste groups (which leaves some possibility of being considered as different genetic pools) it was decided to have villages with population group which can be considered as one genetic pool. Systematic random sampling was used for both these steps. Every $3^{\text {rd }}$ household was selected for the collection of data on height. In the second step, adult tribal males were selected from every $5^{\text {th }}$ household. In total, twenty adult tribal males were selected from each village (ten from each age-group).

For the assessment of the intergenerational variation in adult height, the height of 573 tribal males were measured which constituted 56.96 percent of the total universe. For understanding the determinants of height, 120 childhood histories were collected which constitute 11.93 percent of the total universe. Furthermore, during the analysis one tribal caste (Bheel) were excluded from the analysis of the determinants in order to maintained uniformity in data analysis. So, the determinates of height were assessed based on the 100 childhood histories. 


\section{Data Analysis and Interpretation}

The data entry process was done in MS Excel (Microsoft Corporation, 1990). Statistical Packages for Social Sciences, 16.0 version (SPSS) was used for data analysis in the study (SPSS IBM, 2011).During data interpretation, a conscious attempt was made to avoid such bias.

\section{Result and Discussion}

The trends of height in the selected two generations have been studied through a sample of 573. 81 respondents out of 573 were from the Bhils caste (a sub group of Meena community) while the remaining 492 were Meena. The heights of these two sub groups have been analysed separately.

The economy of the group one village mostly depended on daily wage labour and agriculture. The villages of this group have lower agricultural advantage compared to group two villages due to the topography of the villages. Agriculture was mostly rain fed, especially of the agricultural land owned by the Meena's and Bhil's. In this group of villages, the two villages of Ghati and Panikotada, due their proximity to the lake, had fishing as one of the important occupation. However, only Bhil community traditionally practiced fishing on the lake. Ghati and Panikotada were multi- caste villages where the study population of Meena were just one of the social groups.

Group two villages also have similar agricultural pattern and are dependent on rain water. Despite Morila being on the bank of a small river, it does not have any advantage for irrigation because of its topography (hilly terrain). Due to the lack of irrigation canals and higher attitude of the villages, these villages are not benefitted from the Ambamata dam located near these villages. The hills have come to an advantage to these village as some of the hills are now marble mines. There are five functional marble mines in this area providing good employment opportunity to people from the region.

\section{Respondent Profile}

The pooled data showed (table 1) that the average height of Meena and Bhil community improved over a period of time. However, the group one villages showed decline in the average height of the adult while group two showed significant improvement in the average height of adults.

As discussed Bhil community are involved in fishing and in 1972, the government of Rajasthan provided legal rights of fishing in the lake that increased the consumption of fish and economic status of this community. So, that might be the reason of Bhil community showed improvement in the average adult height.

Table 1: Caste wise distribution of mean height of adult tribal male according to age group (n=573)

\begin{tabular}{|c|c|c|c|c|c|c|c|}
\hline \multirow{2}{*}{ Village group } & \multirow[b]{2}{*}{ Age Group } & \multicolumn{2}{|c|}{ Meena } & \multicolumn{2}{|c|}{ Bhil } & \multirow{2}{*}{$\begin{array}{c}\text { Difference } \\
\text { (Bhil and } \\
\text { Meena) }\end{array}$} & \multirow[b]{2}{*}{ P-Value } \\
\hline & & $\mathbf{N}$ & Mean & $\mathbf{N}$ & Mean & & \\
\hline \multirow{4}{*}{$\begin{array}{l}\text { Group One } \\
\text { Villages } \\
\text { (Ghati, } \\
\text { Panikotada, } \\
\text { Kalimagari) }\end{array}$} & $20-40$ years & $\begin{array}{c}106 \\
(18.50 \%)\end{array}$ & $161.65 \pm 5.02$ & $\begin{array}{c}61 \\
(10.65 \%)\end{array}$ & $162.60 \pm 4.91$ & 0.95 & 0.23 \\
\hline & $40-60$ years & $\begin{array}{c}88 \\
(15.36 \%)\end{array}$ & $162.70 \pm 5.58$ & $\begin{array}{c}20 \\
(3.49 \%)\end{array}$ & $160.92 \pm 5.30$ & -1.78 & 0.19 \\
\hline & Total & $\begin{array}{c}194 \\
(33.86 \%)\end{array}$ & $162.13 \pm 5.30$ & $\begin{array}{c}81 \\
(14.14 \%)\end{array}$ & $162.19 \pm 5.03$ & 0.06 & 0.57 \\
\hline & $\begin{array}{l}\text { Mean } \\
\text { differences }\end{array}$ & & $\begin{array}{c}-1.05 \\
(p-0.17)\end{array}$ & & $\begin{array}{c}1.68 \\
(P-0.21) \\
\end{array}$ & & \\
\hline \multirow{4}{*}{$\begin{array}{l}\text { Group Two } \\
\text { villages } \\
\text { (Morila, Ven, } \\
\text { Sarwani) }\end{array}$} & $20-40$ years & $\begin{array}{c}205 \\
(35.78 \%)\end{array}$ & $162.91 \pm 5.56$ & NA & NA & NA & NA \\
\hline & $40-60$ years & $\begin{array}{c}93 \\
(16.23 \%)\end{array}$ & $160.75 \pm 5.78$ & NA & NA & NA & NA \\
\hline & Total & $\begin{array}{c}298 \\
(52.01 \%)\end{array}$ & $162.23 \pm 5.71$ & NA & NA & NA & NA \\
\hline & $\begin{array}{l}\text { Mean } \\
\text { differences }\end{array}$ & & $\begin{array}{c}2.17 \\
(p-0.002)\end{array}$ & NA & NA & NA & NA \\
\hline \multirow{4}{*}{ Total } & $20-40$ years & $\begin{array}{c}311 \\
(54.28 \%) \\
\end{array}$ & $162.48 \pm 5.41$ & $\begin{array}{c}61 \\
(10.65 \%)\end{array}$ & $162.60 \pm 4.91$ & 0.12 & 0.85 \\
\hline & $40-60$ years & $\begin{array}{c}181 \\
(31.59 \%)\end{array}$ & $161.70 \pm 5.75$ & $\begin{array}{c}20 \\
(3.49 \%) \\
\end{array}$ & $160.92 \pm 5.30$ & -0.78 & 0.54 \\
\hline & Total & $\begin{array}{c}492 \\
(85.86 \%)\end{array}$ & $162.19 \pm 5.54$ & $\begin{array}{c}81 \\
(14.14 \%)\end{array}$ & $162.19 \pm 5.03$ & 0.00 & 0.99 \\
\hline & $\begin{array}{l}\text { Mean } \\
\text { differences }\end{array}$ & & $\begin{array}{c}0.78 \\
(p-0.13)\end{array}$ & & $\begin{array}{c}1.68 \\
(P-0.29)\end{array}$ & & \\
\hline
\end{tabular}




\section{Socio-economic factors}

Minimum three acres of land is required to produce food grain (cereals) which would be sufficient to provide for a family of two adult and two children, for a year; given that there is average monsoon, even if there is no alternative irrigation facility.

Table 2: Age wise distribution of mean height of tribal male according to land availability in their childhood

\begin{tabular}{|c|c|c|c|c|c|c|c|}
\hline \multirow[t]{2}{*}{ Village } & \multirow{2}{*}{$\begin{array}{l}\text { Acre(s) } \\
\text { Age group }\end{array}$} & \multicolumn{3}{|c|}{ less than 3 acre(s) } & \multicolumn{3}{|c|}{ more than 3 acre(s) } \\
\hline & & $N(\%)$ & Height & SD & $\mathbf{N}(\%)$ & Height & SD \\
\hline \multirow{3}{*}{$\begin{array}{l}\text { Ghati, } \\
\text { Kalimagari }\end{array}$} & 20-40 Years & 17.00 & 159.29 & 4.90 & 3.00 & 163.47 & 6.49 \\
\hline & $40-60$ years & 16.00 & 161.04 & 5.18 & 4.00 & 164.48 & 5.34 \\
\hline & Total & 33.00 & 160.14 & 5.04 & 7.00 & 164.04 & 5.35 \\
\hline \multirow{3}{*}{$\begin{array}{l}\text { Morila, } \\
\text { Sarwani, } \\
\text { Ven }\end{array}$} & 20-40 Years & 22.00 & 163.02 & 6.88 & 8.00 & 163.69 & 8.66 \\
\hline & $40-60$ years & 22.00 & 163.15 & 6.07 & 8.00 & 161.69 & 3.94 \\
\hline & Total & 44.00 & 163.09 & 6.41 & 16.00 & 162.69 & 6.58 \\
\hline \multicolumn{2}{|c|}{ Total $(n=100)$} & 77.00 & 161.83 & 6.01 & 23.00 & 163.10 & 6.14 \\
\hline
\end{tabular}

Availability of adequate land would help in the production of adequate quantity of food grain which would translate into adequate food grain consumption. An appropriate amount nutritional intake is required to attain the genetic potential of individual height (Deaton, 2007). Group two villages are in the plain with more agricultural land available for cultivation. Table 2 shows that on an average, those who had more than three acres land were taller compared to those who owned less than three acres. However, these differences were not statistically significant. It was observed that the discrepancy in the group two village, where population with land more than 3 acres have height lower than that of population group with land less than 3 acres, can be explained because of the availability of viable and regular alternative employment option in the mines. Average land holding of this group of villages is better as compared to group one villages. The group one villages are located on the bank of Jaisamand Lake. The agricultural land in these villages is available for cultivation only during the winter and summer when the water of the Lake recedes.

\section{Food Availability and Dietary Intake}

As field data explained, more than $90 \%$ households did not produce enough food grain that would last a family for the whole year. Evidence from the earlier studies showed that agricultural performance has significant negative relationship with the indicators of undernutrition among adult and children (Gulati, Kumar, Shreedhar, \& Nandakumar, 2012; Pandey, Mahendra Dev, \& Jayachandran, 2016; Shively, Sununtnasuk, \& Brown, 2012; Webb \& Block, 2012). Direct approaches, i.e. land reform and raising the agricultural productivity of small landholder, contributed to improvement of the nutritional status (Fleuret \& Fleuret, 1980). Increase of agricultural production has a possibility of increase in food grain consumption. As the days of foods shortage started increasing, the average height adult showing significant reduction (p-0.001) (fig. 1). Earlier discussion clearly explained the difference between both groups of villages.

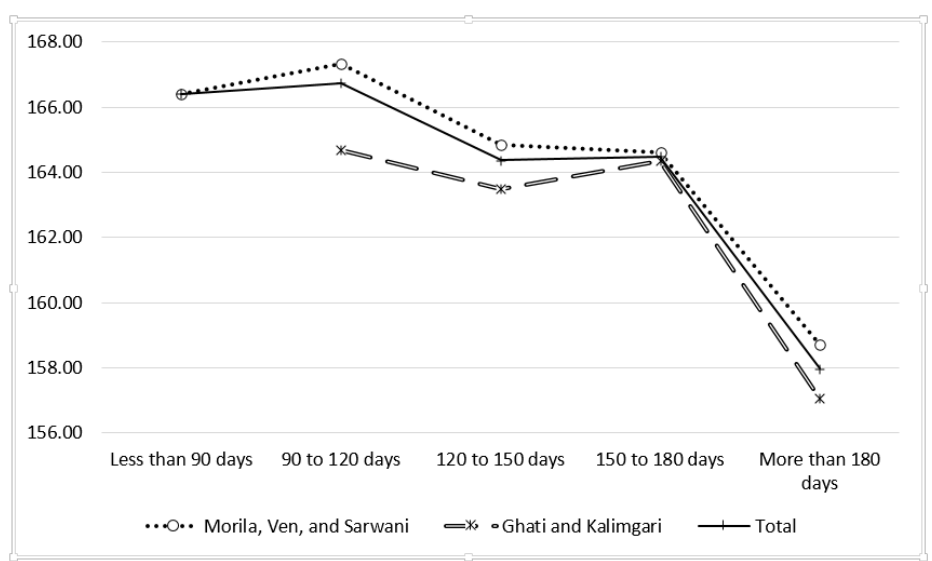

Fig. 1: Age wise distribution of mean height of tribal adult males according to family feel food grain shortage (in days) round the year 
Table 3: Age and village group wise distribution of mean height of tribal male according to frequency of pulses consumption in a week during their childhood

\begin{tabular}{|c|c|c|c|c|c|c|c|c|c|}
\hline \multirow[t]{2}{*}{ Village } & \multirow{2}{*}{$\begin{array}{c}\text { Duration } \\
\text { Age } \\
\text { group } \\
\end{array}$} & \multicolumn{2}{|c|}{$\begin{array}{l}\text { No consumption } \\
\text { in week }\end{array}$} & \multicolumn{2}{|c|}{ once in a week } & \multicolumn{2}{|c|}{ twice in a week } & \multicolumn{2}{|c|}{ thrice in a week } \\
\hline & & $\mathbf{N}(\%)$ & Height & $\mathrm{N}(\%)$ & Height & $\mathbf{N}(\%)$ & Height & $\mathrm{N}(\%)$ & Height \\
\hline \multirow{3}{*}{$\begin{array}{l}\text { Group } \\
\text { One } \\
\text { Villages }\end{array}$} & $\begin{array}{l}20-40 \\
\text { Years }\end{array}$ & 0.00 & . & 13.00 & $\begin{array}{c}159.58 \\
\pm 4.38\end{array}$ & 7.00 & $\begin{array}{c}160.54 \\
\pm 6.81\end{array}$ & 0.00 & . \\
\hline & $\begin{array}{l}40-60 \\
\text { years }\end{array}$ & 6.00 & $\begin{array}{c}164.48 \\
\pm 3.83 \\
\end{array}$ & 12.00 & $\begin{array}{r}160.37 \\
\pm 5.60 \\
\end{array}$ & 2.00 & $\begin{array}{c}161.65 \\
\pm 6.29 \\
\end{array}$ & 0.00 & . \\
\hline & Total & 6.00 & $\begin{array}{c}164.48 \\
\pm 3.83\end{array}$ & 25.00 & $\begin{array}{c}159.96 \\
\pm 4.91\end{array}$ & 9.00 & $\begin{array}{c}160.79 \\
\pm 6.33\end{array}$ & 0.00 & . \\
\hline \multirow{3}{*}{$\begin{array}{l}\text { Group } \\
\text { Two } \\
\text { villages }\end{array}$} & $\begin{array}{l}20-40 \\
\text { Years }\end{array}$ & 0.00 & . & 15.00 & $\begin{array}{c}161.77 \\
\pm 6.09\end{array}$ & 13.00 & $\begin{array}{c}163.54 \\
\pm 8.14\end{array}$ & 2.00 & $\begin{array}{c}171.75 \\
\pm 5.30\end{array}$ \\
\hline & $\begin{array}{l}40-60 \\
\text { years }\end{array}$ & 12.00 & $\begin{array}{c}164.15 \\
\pm 5.08 \\
\end{array}$ & 16.00 & $\begin{array}{c}162.70 \\
\pm 5.57 \\
\end{array}$ & 2.00 & $\begin{array}{l}154.95 \\
\pm 0.07 \\
\end{array}$ & 0.00 & 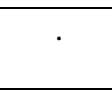 \\
\hline & Total & 12.00 & $\begin{array}{c}164.15 \\
\pm 5.08\end{array}$ & 31.00 & $\begin{array}{c}162.25 \\
\pm 5.75\end{array}$ & 15.00 & $\begin{array}{c}162.39 \\
\pm 8.12\end{array}$ & 2.00 & $\begin{array}{c}171.75 \\
\pm 5.30\end{array}$ \\
\hline \multicolumn{2}{|c|}{ Total $(n=100)$} & 18.00 & $\begin{array}{c}164.26 \\
\pm 4.59\end{array}$ & 56.00 & $\begin{array}{l}161.23 \\
\pm 5.47\end{array}$ & 24.00 & $\begin{array}{c}161.79 \\
\pm 7.39\end{array}$ & 2.00 & $\begin{array}{c}171.75 \\
\pm 5.30\end{array}$ \\
\hline
\end{tabular}

The frequency of pulses consumption in a week and height gain have significant positive relationship (p-0.03, table 3). Energy-adjusted protein from different sources (animal, pulses, and vegetables) and the total energy-adjusted protein were associated with height and weight gain, after the controlling for sex, age, land ownership, diarrhoea, ARI and fiver (Torres, Orav, Willett, \& Chen, 1994). The consumption of Pulses or legume is beneficial for prevention and control of disease (Campos-Vega, Loarca-Piña, \& Oomah, 2010; Tharanathan \& Mahadevamma, 2003), which might aid in the height growth.

Table 4: Age and village group wise distribution of mean height of tribal male according to frequency of consumption of non-vegetarian based diet in their growing age

\begin{tabular}{|c|c|c|c|c|c|c|c|c|c|}
\hline \multirow[t]{2}{*}{ Village } & \multirow[t]{2}{*}{ Age } & \multicolumn{2}{|c|}{ Once in a week } & \multicolumn{2}{|c|}{ once in fortnight } & \multicolumn{2}{|c|}{ once in a month } & \multicolumn{2}{|c|}{$\begin{array}{c}\text { few time in a } \\
\text { year }\end{array}$} \\
\hline & & $\mathbf{N}(\%)$ & Height & $\mathrm{N}(\%)$ & Height & $\mathrm{N}(\%)$ & Height & $\mathbf{N}(\%)$ & Height \\
\hline \multirow{3}{*}{$\begin{array}{l}\text { Group } \\
\text { One } \\
\text { Villages }\end{array}$} & $\begin{array}{l}20-40 \\
\text { Years }\end{array}$ & 10.42 & $\begin{array}{c}161.96 \\
\pm 4.04\end{array}$ & 2.08 & $\begin{array}{c}157.95 \\
\pm 1.34\end{array}$ & 5.21 & $\begin{array}{c}154.18 \\
\pm 4.65\end{array}$ & 3.13 & $\begin{array}{c}164.00 \\
\pm 2.65\end{array}$ \\
\hline & $\begin{array}{l}40-60 \\
\text { years }\end{array}$ & 13.54 & $\begin{array}{c}163.95 \\
\pm 4.72\end{array}$ & 2.08 & $\begin{array}{c}155.00 \\
\pm 3.11\end{array}$ & 4.17 & $\begin{array}{c}158.05 \\
\pm 3.59\end{array}$ & 0 & \\
\hline & Total & 23.96 & $\begin{array}{c}163.09 \\
\pm 4.46\end{array}$ & 4.17 & $\begin{array}{l}156.48 \\
\pm 2.59\end{array}$ & 9.38 & $\begin{array}{c}155.90 \\
\pm 4.45\end{array}$ & 3.13 & $\begin{array}{c}164.00 \\
\pm 2.65\end{array}$ \\
\hline \multirow{3}{*}{$\begin{array}{l}\text { Group } \\
\text { Two } \\
\text { villages }\end{array}$} & $\begin{array}{l}20-40 \\
\text { Years }\end{array}$ & 14.58 & $\begin{array}{c}164.13 \\
\pm 5.13 \\
\end{array}$ & 1.04 & 165 & 9.38 & $\begin{array}{c}165.58 \\
\pm 6.05\end{array}$ & 5.21 & $\begin{array}{l}155.00 \\
\pm 10.74\end{array}$ \\
\hline & $\begin{array}{l}40-60 \\
\text { years }\end{array}$ & 21.88 & $\begin{array}{c}162.47 \\
\pm 6.19\end{array}$ & 2.08 & $\begin{array}{l}165.95 \\
\pm 4.45\end{array}$ & 4.17 & $\begin{array}{c}164.20 \\
\pm 1.97\end{array}$ & 1.04 & 154.9 \\
\hline & Total & 36.46 & $\begin{array}{c}163.13 \\
\pm 5.77\end{array}$ & 3.13 & $\begin{array}{c}165.63 \\
\pm 3.20\end{array}$ & 13.54 & $\begin{array}{c}165.15 \\
\pm 5.08\end{array}$ & 6.25 & $\begin{array}{c}154.98 \\
\pm 9.60\end{array}$ \\
\hline \multicolumn{2}{|c|}{ Total $(n=96)$} & 60.42 & $\begin{array}{c}163.12 \\
\pm 5.25\end{array}$ & 7.29 & $\begin{array}{c}160.40 \\
\pm 5.54\end{array}$ & 22.92 & $\begin{array}{c}161.37 \\
\pm 6.63\end{array}$ & 9.38 & $\begin{array}{c}157.99 \\
\pm 8.93\end{array}$ \\
\hline
\end{tabular}

The frequency of non-vegetarian food consumption was positively correlated with the average height of people, but the same was not statistically significant (Table No. 4). Group two villages were surrounded by huge forest that provided advantage in terms of wild animal food while there was no such possibility for the group one villages. Therefore, this could also factor in as to why the average height of group two villages was better. The intergeneration changes also observed that the average height of current generation showed decline in group one villages while the group two villages showed improvement in average height of an adult. It can be explained by the deforestation that led to reduction in the availability of wild animals. However, the effect of decreasing number of the wild animal did not affect the average height of group two villages. Indeed, the availability of employment opportunity in mining might have supported the height gain of the 
group two villages. So, the effect of decreasing number of wild animal did not have much effect on the height of group two villages. The comparison of average height between those who consume vegetarian and those who consume non-vegetarian diet showed that vegetarians were taller than non-vegetarians.The available literature has mixed finding about the relationship between height and vegetarian/nonvegetarian diet. some of study support that vegetarian diet for height gain (Khanna, Lal, Kommi, \& Chakraborty, 2006; Nathan, Hackett, \& Kirby, 1997; Mamidi, Kulkarni, \& Singh, 2011).

Table 5: Age and village group wise distribution of mean height of tribal male according to consumption of dairy products during their childhood

\begin{tabular}{|l|l|c|c|c|c|c|c|}
\hline \multirow{2}{*}{ Village } & Age group & \multicolumn{3}{|c|}{ Yes } & \multicolumn{3}{c|}{ No } \\
\cline { 3 - 8 } & & $\mathbf{N}(\boldsymbol{\%})$ & Height & SD & N (\%) & Height & SD \\
\hline \multirow{3}{*}{$\begin{array}{l}\text { Group One } \\
\text { Villages }\end{array}$} & $20-40$ Years & 9.00 & 163.50 & 3.65 & 11.00 & 156.99 & 4.44 \\
\cline { 2 - 8 } & $40-60$ years & 9.00 & 165.30 & 2.65 & 11.00 & 158.81 & 5.11 \\
\cline { 2 - 8 } & Total & 18.00 & 164.40 & 3.23 & 22.00 & 157.90 & 4.76 \\
\hline \multirow{3}{*}{$\begin{array}{l}\text { Group Two } \\
\text { villages }\end{array}$} & $20-40$ Years & 22.00 & 165.35 & 6.01 & 8.00 & 157.28 & 7.37 \\
\cline { 2 - 8 } & $40-60$ years & 19.00 & 165.26 & 3.82 & 11.00 & 158.45 & 5.55 \\
\cline { 2 - 8 } & Total & 41.00 & 165.31 & 5.05 & 19.00 & 157.95 & 6.21 \\
\hline \multirow{5}{*}{ Total } & 20-40 Years & 31.00 & 164.82 & 5.43 & 19.00 & 157.11 & 5.66 \\
\cline { 2 - 8 } & $40-60$ years & 28.00 & 165.28 & 3.44 & 22.00 & 158.63 & 5.21 \\
\cline { 2 - 8 } & $\begin{array}{l}\text { Total } \\
(\mathrm{n}=100)\end{array}$ & 59.00 & 165.03 & 4.56 & 41.00 & 157.92 & 5.41 \\
\hline
\end{tabular}

Consumption of dairy products during the childhood significantly associated with height gain (Baten, 2009; de Beer, 2012; Orr, 1928; Rizzoli, 2014; Xueqin et al., 2004). The pooled data showed that the current generation are shorter than the earlier generation (table 5). That difference could be explained by the availability of milk products throughout the year. As social history explained that earlier generation had the advantage of the availability of derivative products of milk throughout the year.

\section{Hunger and Height}

Hunger during the growing age put significant impact on the height growth process (table 6). The history of hunger effect on average height of group one villages was higher as compared to the group two villages. The current generation of the group one villages showed similar pattern of pooled data of current generation while the group two villages current generation are shorter than those who faced hunger in their growing age. However, the number of those in current generation who faced hunger during their growing years have declined as compared to the earlier generation because improvement in the agricultural aids and technological innovation led to increase in the food grain productions. The decline in the average height of adult might be explained by changes in diets (from coarse cereals Kuri, Kagani, sorghum to wheat). Gerard et al. (2016) study estimates the causal effects of early life hunger on the late-life health of European countries. It includes birth cohort exposed to various famines in the 20th century and finds that the effect of hunger at the age of 6-16 years of male and female does not significantly affect the adult height (Berg, Pinger, \& Schoch, 2016). Chinese famine found that those who exposed to famine in first five years of life are stunted by 1 to $2 \mathrm{~cm}$. and this stunting might also effect the final height attained (Gørgens, Meng, \& Vaithianathan, 2012).

Table 6: Age wise distribution of mean height of tribal male according to the history hunger during the childhood

\begin{tabular}{|c|l|c|c|c|c|c|c|}
\hline Village & Age group & \multicolumn{3}{|c|}{ Yes } & \multicolumn{3}{|c|}{ No } \\
\cline { 2 - 8 } & & $\mathbf{N}(\%)$ & Height & SD & N (\%) & Height & SD \\
\hline \multirow{3}{*}{$\begin{array}{c}\text { Group One } \\
\text { Villages }\end{array}$} & $20-40$ Years & 11.00 & 158.48 & 3.29 & 9.00 & 161.68 & 6.66 \\
\cline { 2 - 8 } & $40-60$ years & 15.00 & 160.33 & 4.92 & 5.00 & 165.94 & 4.16 \\
\cline { 2 - 8 } & Total & 26.00 & 159.55 & 4.33 & 14.00 & 163.20 & 6.09 \\
\hline \multirow{3}{*}{$\begin{array}{c}\text { Group Two } \\
\text { villages }\end{array}$} & $20-40$ Years & 19.00 & 160.41 & 7.10 & 11.00 & 168.02 & 4.58 \\
\cline { 2 - 8 } & $40-60$ years & 24.00 & 161.48 & 4.70 & 6.00 & 167.92 & 6.12 \\
\cline { 2 - 8 } & Total & 43.00 & 161.00 & 5.83 & 17.00 & 167.98 & 4.99 \\
\hline \multirow{2}{*}{ Total } & $20-40$ Years & 30.00 & 159.70 & 5.99 & 20.00 & 165.17 & 6.34 \\
\cline { 2 - 8 } & $40-60$ years & 39.00 & 161.03 & 4.75 & 11.00 & 167.02 & 5.17 \\
\cline { 2 - 8 } & $\begin{array}{l}\text { Total } \\
\text { (n=100) }\end{array}$ & 69.00 & 160.46 & 5.33 & 31.00 & 165.82 & 5.93 \\
\hline
\end{tabular}




\section{Childhood Disease and Height}

Table 7: Village and Age wise distribution of mean height of tribal male according to history of prolonged major disease

\begin{tabular}{|c|l|c|c|c|c|c|c|}
\hline Village & Age group & \multicolumn{3}{|c|}{ yes } & \multicolumn{3}{c|}{ No } \\
\cline { 3 - 8 } & & $\mathbf{N}(\%)$ & Height & $\begin{array}{c}\text { Standard } \\
\text { Deviation }\end{array}$ & $\begin{array}{c}\mathbf{N} \\
(\%)\end{array}$ & Height & $\begin{array}{c}\text { Standard } \\
\text { Deviation }\end{array}$ \\
\hline \multirow{2}{*}{$\begin{array}{c}\text { Group } \\
\text { One } \\
\text { Villages }\end{array}$} & $20-40$ Years & 16.00 & 158.54 & 4.86 & 4.00 & 165.43 & 1.60 \\
\cline { 2 - 8 } & $40-60$ years & 17.00 & 160.79 & 5.08 & 3.00 & 167.07 & 2.42 \\
\hline \multirow{2}{*}{$\begin{array}{c}\text { Group } \\
\text { Two } \\
\text { villages }\end{array}$} & Total & 33.00 & 159.70 & 5.03 & 7.00 & 166.13 & 2.00 \\
\cline { 2 - 8 } & $40-40$ Years & 24.00 & 162.17 & 7.27 & 6.00 & 167.33 & 5.96 \\
\cline { 2 - 8 } Total & Total years & 27.00 & 162.83 & 5.83 & 3.00 & 162.17 & 2.20 \\
\cline { 2 - 8 } & $20-40$ Years & 51.00 & 162.52 & 6.49 & 9.00 & 165.61 & 5.48 \\
\cline { 2 - 8 } & T0-60 years & 44.00 & 160.72 & 6.59 & 10.00 & 166.57 & 4.64 \\
\hline
\end{tabular}

The occurrence of major prolonged disease during the growing age and height gain in later life is inversely correlated (p-0.001). Group one villages show more susceptibility to slower height gain because of prolonged/major diseases in childhood as compared to group two villages (table 7). This could be because of poor access to medical care in these difficult to reach villages. As social history explained, the distance from community health centre to group one villages is more than that of group two villages; that would perhaps explain the higher number of the earlier generation in category one. The reduction in the number of current generation among who suffered from prolonged disease would be explained by the improvement in health service and better connectivity than earlier generation.

Table 8: Age wise distribution of mean height of tribal male according to history of recurrence of disease in childhood

\begin{tabular}{|l|l|l|c|c|c|c|c|}
\hline \multirow{2}{*}{ Village } & \multirow{2}{*}{ Age Group } & \multicolumn{3}{|c|}{ Yes } & \multicolumn{3}{c|}{ No } \\
\cline { 3 - 8 } & & $\mathbf{N}(\%)$ & Height & SD & N $(\%)$ & Height & SD \\
\hline \multirow{3}{*}{$\begin{array}{l}\text { Group One } \\
\text { Villages }\end{array}$} & $20-40$ Years & 19.00 & 159.76 & 5.29 & 1.00 & 163.00 &. \\
\cline { 2 - 8 } & $40-60$ years & 17.00 & 160.68 & 4.98 & 3.00 & 167.67 & 1.40 \\
\cline { 2 - 8 } & Total & 36.00 & 160.19 & 5.09 & 4.00 & 166.50 & 2.60 \\
\hline \multirow{2}{*}{$\begin{array}{l}\text { Group } \\
\text { Two } \\
\text { villages }\end{array}$} & $20-40$ Years & 23.00 & 162.18 & 7.32 & 7.00 & 166.56 & 6.33 \\
\cline { 2 - 8 } Total & $40-60$ years & 24.00 & 162.51 & 6.11 & 6.00 & 163.77 & 2.34 \\
\cline { 2 - 8 } & Total & 47.00 & 162.35 & 6.66 & 13.00 & 165.27 & 4.94 \\
\cline { 2 - 8 } & 20-40 Years & 42.00 & 161.08 & 6.52 & 8.00 & 166.11 & 5.99 \\
\cline { 2 - 8 } & To-60 years & 41.00 & 161.75 & 5.68 & 9.00 & 165.07 & 2.78 \\
\cline { 2 - 8 }$(\mathrm{n}=100)$ & 83.00 & 161.41 & 6.09 & 17.00 & 165.56 & 4.45 \\
\hline
\end{tabular}

Reported recurrence of diseases significant and inversely associated with height gain (p-0.001). Those who did not report any recurrence of disease showed intergeneration height gain in group one and group two of about $4.67 \mathrm{~cm}$ and $2.79 \mathrm{~cm}$, respectively (table 8 ).

The major diseases showing recurrence in growing age were diarrhoea and guinea worm infestation. The diarrheal prevalence in group one villages could be explained with source of drinking water, because the major source of drinking water for the group one was
Jaisamand lake and that was reported more frequently with the diarrheal incident (fig.6.3 and 6.4). The Number of guinea worm infestation were higher in earlier generation in both village groups while number the same in current generation is very less. The Government of India started Guinea Worm Eradication program in 1983-84. In February 2009, WHO certified India as Guinea Worm disease free country (Government of India, 2011). 


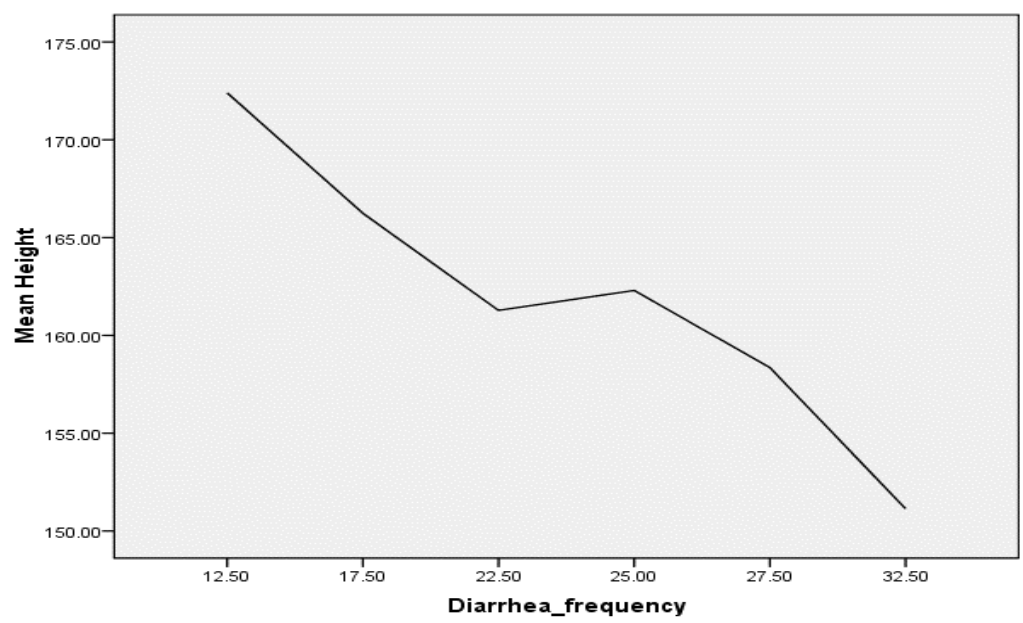

Fig. 2: Distribution of mean height of tribial male and frequency of diarrhea

The frequency of diarrhoea during the growing age is inversely associated with height of the individual (Fig. 2) (Daniels, Cousens, Makoae, \& Feachem, 1991; Hoddinott, 1997; Lima et al., 1992; Richard et al., 2013; Victora, Barros, Kirkwood, \& Vaughan, 1990). The higher burden of diarrhea prior to 24 months of the life cycle was associated with a greater risk of stunting at the age of 24 months (Checkley et al., 2008; Checkley, Epstein, Gilman, Cabrera, \& Black, 2003).
The average height was more for those people who fetched water from the Open and Natural well as compared with those fetching from river and lake. The existing difference in average height, across the source of drinking water, might be due to the quality of water. The quality of water affects average height through incidence of diarrhoea. The assumption that lake and river water is relatively unsafe and has impact on average height gain through repeated diarrhoea attacks is backed by the data in the Fig. 3 and 4 .

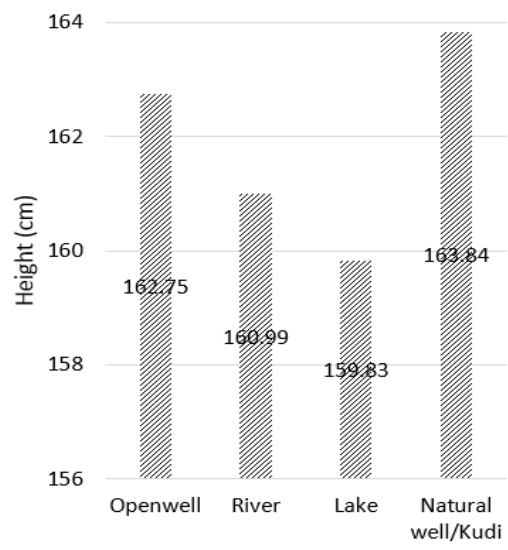

Fig. 3: Source of drinking water and average height

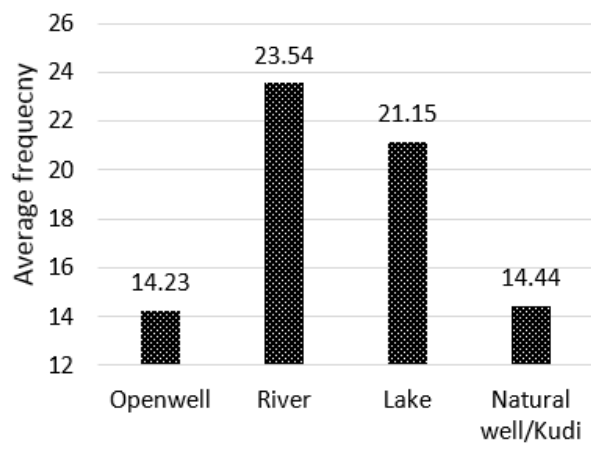

Fig. 4: Average Frequency of Diarrhea Occurrence and Source of Drinking Water 


\section{Using of Health care service}

Table 9: Village and Age wise distribution of mean height of tribal male according to regular used to medical care during childhood

\begin{tabular}{|l|l|c|c|c|c|c|c|}
\hline Village & Age group & Yes & & & No & & \\
\cline { 3 - 8 } & & $\mathbf{N}(\boldsymbol{\%})$ & Height & $\begin{array}{l}\text { Standard } \\
\text { Deviation }\end{array}$ & $\mathbf{N}(\boldsymbol{\%})$ & Height & $\begin{array}{c}\text { Standard } \\
\text { Deviation }\end{array}$ \\
\hline \multirow{2}{*}{$\begin{array}{l}\text { Group One } \\
\text { Villages }\end{array}$} & $20-40$ Years & 16.67 & 158.37 & 5.03 & 2.38 & 159.75 & 4.60 \\
\cline { 2 - 8 } & $40-60$ years & 5.95 & 159.22 & 5.41 & 14.29 & 161.44 & 5.03 \\
\cline { 2 - 8 } & Total & 22.62 & 158.59 & 5.00 & 16.67 & 161.20 & 4.84 \\
\hline \multirow{2}{*}{$\begin{array}{l}\text { Group Two } \\
\text { villages }\end{array}$} & $20-40$ Years & 25.00 & 161.32 & 7.34 & 3.57 & 168.10 & 2.82 \\
\cline { 2 - 8 } & $40-60$ years & 10.71 & 160.03 & 4.42 & 21.43 & 164.23 & 6.05 \\
\cline { 2 - 8 } & Total & 35.71 & 160.93 & 6.55 & 25.00 & 164.78 & 5.82 \\
\hline \multirow{3}{*}{ Total } & $20-40$ Years & 41.67 & 160.14 & 6.60 & 5.95 & 164.76 & 5.49 \\
\cline { 2 - 8 } & $40-60$ years & 16.67 & 159.74 & 4.60 & 35.71 & 163.11 & 5.74 \\
\cline { 2 - 8 } & Total (n=84) & 58.33 & 160.03 & 6.05 & 41.67 & 163.35 & 5.66 \\
\hline
\end{tabular}

Among those who used the regular medical care during the childhood illness, the average height was significantly lower than those who did not practise the same (p-0.013, table 9). Tribals living in such circumstances with poor accessibility to medical care service are likely to use medical service only when the disease condition becomes severe. So, the using medical care may be taken as a proxy for the severity of disease. This further proves the relationship between childhood disease and height gain in later life. Those who did not have any major disease in growing age were significantly taller than those who suffered.

The chief of Niti Ayog, Dr. Panagariya argues that low height and weight among Indian was due to genetic, and nutritional anthropometry was not appropriate in terms of Indian context, because, in India, have different genetics. He argued that sample from the healthy population of Delhi did not represent the healthy children of the whole country (Panagariya \& Bhagwati, 2013). However, the 8,440 sampled from the healthy children of Delhi was evidence (not "assumptions") for WHO new growth reference, and it reviewed by numerous experts and governments over many years (Gillespie, 2013).

Panagariya argued that India has a higher proportion of malnourished children than Sub-Saharan African (SSA) countries despite lower mortality and higher economic growth. He explained Indian and African puzzle with drawn their literature corroborated with Mortality data and economic indicators, and finally concluded that Indian are shorter due to their low genetic potential and a higher proportion of malnutrition is due to inappropriate anthropometry (ibid). However, a uniformly acceptable indicator that measured the genetic potential at the individual or population level still not developed. On the basis of Mid-Parents Height (MPH), we can predict the genetic potential of the height of the children (Parmar, Makwana, Hapani, Kalathia, \& Doshi, 2014).
Panagariya compared India with Chad on the basis of health indicators such as mortality, life expectancy, and other nutritional indices like stunting and wasting, while he is completely silent on an environmental factor such as sanitation. India has huge open defecation compared with Chad. In Chad, an average seven neighbors who defecate in the open per square $\mathrm{km}$ while in India, on average over 200 people defecate per square km (Coffey, Deaton, Drèze, Spears, \& Tarozzi, 2013). Same as in China, about 1 percent defecate in the open. Sub-Saharan Africa and India, a large fraction of different in average height, can be explained by the prevalence of open defecation(Coffey et al., 2013; Spears, 2013). GargiWable note that 'Controlling for GDP, the difference between Nigeria's $26 \%$ open defecation rate and India's $55 \%$ is associated with an increase in child height approximately equivalent to quadrupling GDP per capita'-(Wable, 2013)

\section{Conclusion}

The intergenerational variation showed mixed result between both village groups. Group one villages showed decline whine group two villages showed significant improvement in the average height of current generation. However, pooled data showed marginally improvement in the average height of the current generation. The history of development of the villages is different and its affect the height of adult in different ways. The effect of structural changes in the new globalization era mainly in the pattern of food consumption clearly affect average height of the adult. Adequate nutrition intake, lower exposure to disease environment, and better access to health care services is positively and significantly correlated with height gain of the individual.

\section{References}

1. Bailey, R. E., Hatton, T. J., \& Inwood, K. (2016). Health, height, and the household at the turn of the twentieth century. The Economic History Review, 69(1), 35-53.

2. Baten, J. (2009). Protein supply and nutritional status in 
nineteenth century Bavaria, Prussia and France. Economics \& Human Biology, 7(2), 165-180.

3. Berg, G. J., Pinger, P. R., \& Schoch, J. (2016). Instrumental variable estimation of the causal effect of hunger early in life on health later in life. The Economic Journal, 126(591), 465-506.

4. Bogin, B. (1999). Patterns of human growth (Vol. 23). Cambridge University Press.

5. Campos-Vega, R., Loarca-Piña, G., \& Oomah, B. D. (2010). Minor components of pulses and their potential impact on human health. Food Research International, 43(2), 461-482.

https://doi.org/http://doi.org/10.1016/j.foodres.2009.09.00 4

6. Checkley, W., Buckley, G., Gilman, R. H., Assis, A. M. O., Guerrant, R. L., Morris, S. S., ... Black, R. E. (2008). Multi-country analysis of the effects of diarrhoea on childhood stunting. International Journal of Epidemiology, 37(4), 816-830.

7. Checkley, W., Epstein, L. D., Gilman, R. H., Cabrera, L., \& Black, R. E. (2003). Effects of acute diarrhea on linear growth in Peruvian children. American Journal of Epidemiology, 157(2), 166-175.

8. Chesters, J. (2016). Trends in economic growth and levels of wealth inequality in G20 nations: 2001-2013. Contemporary Social Science, 11, 2-3. https://doi.org/10.1080/21582041.2016.1199891

9. Coffey, D., Deaton, A., Drèze, J., Spears, D., \& Tarozzi, A. (2013). Stunting among children: Facts and implications. Economic and Political Weekly, 48(34), 6870.

10. Daniels, D. L., Cousens, S. N., Makoae, L. N., \& Feachem, R. G. (1991). A study of the association between improved sanitation facilities and children's height in Lesotho. European Journal of Clinical Nutrition, 45(1), 23-32.

11. de Beer, H. (2012). Dairy products and physical stature: A systematic review and meta-analysis of controlled trials. Economics \& Human Biology, 10(3), 299-309. https://doi.org/https://doi.org/10.1016/j.ehb.2011.08.003

12. Deaton, A. (2007). Height, health, and development. Proceedings of the National Academy of Sciences, 104(33), 13232-13237.

13. Dougherty, M. J. (1998). Why are we getting taller as a species? Retrieved October 16, 2017, from https://www.scientificamerican.com/article/why-are-wegetting-taller/\#

14. Fleuret, P., \& Fleuret, A. (1980). Nutrition, consumption, and agricultural change. Human Organization, 39(3), 250-260.

15. Garcia, J., \& Quintana-Domeque, C. (2007). The evolution of adult height in Europe: a brief note. Economics \& Human Biology, 5(2), 340-349.

16. Gillespie, S. (2013). Myths and realities of child nutrition. Economic and Political Weekly, 48(34), 64-67.

17. Gørgens, T., Meng, X., \& Vaithianathan, R. (2012). Stunting and selection effects of famine: A case study of the Great Chinese Famine. Journal of Development Economics, 97(1), 99-111.

https://doi.org/https://doi.org/10.1016/j.jdeveco.2010.12.0 05

18. Government of India. (2011). Guinea Worm Eradication Programme (GWEP). National Centre for Disease Control, Directorate General of Health Service, Ministry of Health and Family Welfare. Retrieved May 4, 2017, from http://www.ncdc.gov.in/index2.asp?slid=329\&sublinkid= 216
19. Gulati, A., Kumar, A. G., Shreedhar, G., \& Nandakumar, T. (2012). Agriculture and malnutrition in India. Food and Nutrition Bulletin, 33(1), 74-86.

20. Hatton, T. J., \& Bray, B. E. (2010). Long run trends in the heights of European men, 19th-20th centuries. Economics \& Human Biology, 8(3), 405-413.

21. Hoddinott, J. (1997). Water, health, and income: A review. International Food Policy Research Institute.

22. Khanna, G. L., Lal, P. R., Kommi, K., \& Chakraborty, T. (2006). A comparison of a vegetarian and non-vegetarian diet in Indian female athletes in relation to exercise performance. Journal of Exercise Science and Physiotherapy, 2, 27.

23. Komlos, J., \& Baur, M. (2004). From the tallest to (one of) the fattest: the enigmatic fate of the American population in the 20th century. Economics \& Human Biology, 2(1), 57-74.

24. Lima, A. A. M., Fang, G., Schorling, J. B., Albuquerque, L., McAuliffe, J. F., Mota, S., ... Guerrant, R. L. (1992). Persistent diarrhea in Northeast Brazil: etiologies and interactions with malnutrition. Acta Paediatrica, 81(s383), 39-44.

25. Mamidi, R. S., Kulkarni, B., \& Singh, A. (2011). Secular trends in height in different states of $\{$ India $\}$ in relation to socioeconomic characteristics and dietary intakes. Food and Nutrition Bulletin, 32(1), 23-34.

26. Microsoft Corporation. (1990). Excel 2016. Las Vegas: Microsoft Corporation.

27. Nathan, I., Hackett, A. F., \& Kirby, S. (1997). A longitudinal study of the growth of matched pairs of vegetarian and omnivorous children, aged 7-11 years, in the North-West of England. European Journal of Clinical Nutrition, 51(1).

28. Orr, J. B. (1928). Influence of amount of milk consumption on the rate of growth of school children. British Medical Journal, 1(3499), 140.

29. Panagariya, A., \& Bhagwati, J. (2013). Does India Really Suffer from Worse Child Malnutrition Than Sub-Saharan Africa? Economic \& Political Weekly, 48(18), 98-111.

30. Pandey, V. L., Mahendra Dev, S., \& Jayachandran, U. (2016). Impact of agricultural interventions on the nutritional status in South Asia: A review. Food Policy, $62,28-40$. https://doi.org/http://doi.org/10.1016/j.foodpol.2016.05.0 02

31. Parmar, P. N., Makwana, A. M., Hapani, P. T., Kalathia, M. B., \& Doshi, S. K. (2014). Approach to Tall Stature. Indian Journal of Clinical Practice, 25(5), 424-428. Retrieved from http://medind.nic.in/iaa/t14/i10/iaat14i10p424.pdf

32. Richard, S. A., Black, R. E., Gilman, R. H., Guerrant, R. L., Kang, G., Lanata, C. F., ... Checkley, W. (2013). Diarrhea in Early Childhood: Short-term Association With Weight and Long-term Association With Length. American Journal of Epidemiology, 178(7), 1129-1138. Retrieved from http://dx.doi.org/10.1093/aje/kwt094

33. Rizzoli, R. (2014). Dairy products, yogurts, and bone health. The American Journal of Clinical Nutrition, 99(5), $1256 \mathrm{~S}-1262 \mathrm{~S}$

34. Shively, G., Sununtnasuk, C., \& Brown, M. (2012). Measuring the Links Between Agriculture and Child Health in Nepal. Nutrition CRSP Research Briefing Paper, (10). Retrieved from http://www.nutritioninnovationlab.org/wpcontent/uploads/2013/04/RBP10_Agriculture_Child_Heal th_Nepal_FINAL.pdf

35. Spears, D. (2013). How much international variation in child height can sanitation explain? World Bank Policy 
Research Working Paper No. 6351. Available at SSRN: https://ssrn.com/abstract=2212559

36. SPSS IBM. (2011). IBM SPSS statistics for Windows version 16.0. New York: IBM Corp.

37. Steckel, R. H. (1995). Stature and the Standard of Living. Journal of Economic Literature, 33(4), 1903-1940.

38. Tharanathan, R. N., \& Mahadevamma, S. (2003). Grain legumes - a boon to human nutrition. Trends in Food Science \& Technology, 14(12), 507-518.

39. Torres, A., Orav, J., Willett, W., \& Chen, L. (1994). Association between protein intake and 1-y weight and height gains in Bangladeshi children aged 3-11 y. The American Journal of Clinical Nutrition, 60(3), 448-454.

40. Victora, C. G., Barros, F. C. de, Kirkwood, B. R., \& Vaughan, J. P. (1990). Pneumonia, diarrhea, and growth in the first 4 y of life: a longitudinal study of 5914 urban Brazilian children. The American Journal of Clinical Nutrition, 52(2), 391-396.

41. VOTH, H., \& Leunig, T. (1996). Did smallpox reduce height? Stature and the standard of living in London, 1770-18731. The Economic History Review, 49(3), 541560.

42. Wable, G. (2013). Methodologically deficient, ignorant of prior research. Economic and Political Weekly, 48(34), 60-64.

43. Webb, P., \& Block, S. (2012). Support for agriculture during economic transformation: Impacts on poverty and undernutrition. Proceedings of the National Academy of Sciences, 109(31), 12309-12314.

44. Xueqin, D. U., Zhu, K., Trube, A., Zhang, Q., Ma, G., Hu, X., ... Greenfield, H. (2004). School-milk intervention trial enhances growth and bone mineral accretion in Chinese girls aged 10-12 years in Beijing. British Journal of Nutrition, 92(1), 159-168. 